Срібна Оксана Володимирівна кандидат психологічних наук, доцент кафедри безпеки польотів факультету льотної експлуатації та обслуговування повітряного руху, Льотна Академія Національного авіаційного університету (ЛА НАУ), вул. Добровольського, 1, м. Кропивницький, 25005, тел.: (066) 920-50-17, e-mail: oksana-kd@ukr.net, https://orcid.org/0000-0002-1473-9506

\title{
ПСИХОЛОГІЧНІ ЧИННИКИ МІГРАЦІЙНОЇ ГОТОВНОСТІ УКРАЇНСЬКОЇ МОЛОДІ
}

Анотація. У статті представлено результати теоретико-методологічного та емпіричного дослідження соціальних передумов та психологічних причин еміграції українців. Методи які застосовувались у ході дослідження: анкета міграційної готовності та ціннісно-життєвих орієнтирів сучасних українців; для вивчення психологічної готовності до міграції ми застосували принципи i методи експертної оцінки відповідей наших респондентів - юнаків та дівчат. Міграційна готовність - це психологічне новоутворення, яке в змістовному плані являє собою спрямовану активність, установку на добровільну зміну місця проживання. Міграційна готовність має комплексну детермінацію, тобто джерело міграційної готовності не може бути тільки внутрішнім або тільки зовнішнім. Під міграційними настроями ми маємо на увазі сукупність орієнтацій та мотивів агента, що пов'язані з його бажанням виїзду за кордон 3 різною метою. В межах нашого дослідження ми розглядаємо еміграційні настрої як компонент міграційної готовності сучасного юнацтва в контексті передумов потенційної (можливої) еміграції.

Отримані результати вказують на зневіру, розчарування, відсутність бачення власних перспектив у країні, що безумовно, суттєво впливає на формування міграційної готовності. Можна 3 впевненістю сказати, що міграційні настрої поширені серед української молоді. Елементами міграційної готовності виступають як зовнішні причини (основними з яких є: економіка, безпека, матеріальний стан), так і внутрішні (особливості суб'єктивного образу світу респондентів, їх ціннісні та моральні орієнтації, прагнення до самореалізації). Ключовими мотивами міграції на даний момент є низький рівень доходів і соціально-економічні чинники. Відповідно, мова йде про те, що не задовольняє в Україні: низький рівень доходів, нестабільна політична ситуація і неможливість реалізації свого професійного досвіду.

Ключові слова: міграційна готовність, міграційні настрої, міграційна поведінка, ціннісно-життєвих орієнтирів школярів. 
Sribna Oksana Volodumurivna Candidate of psychological sciences, Associate Professor, Department of Safety and Environment, Faculty of Forestry Operations and Maintenance air traffic service of the National Aviation Academy of Ukraine (NAU), Dobrovolskogo St., 1, Kropivnitskiy, 25005, tel.: 066-920-50-17, e-mail: oksana-kd@ukr.net, https://orcid.org/0000-0002-1473-9506

\title{
PSYCHOLOGICAL FACTORS OF MIGRATION READY OF UKRAINIAN YOUTH
}

\begin{abstract}
The article presents the results of theoretical and methodological and empirical research of social preconditions and psychological causes of emigration of Ukrainians. questionnaire of migration readiness and values of life of modern Ukrainians; to study the psychological readiness for migration, we used the principles and methods of expert assessment of the responses of our respondents boys and girls. migration readiness is a psychological neoplasm, which in terms of content is a directed activity, an attitude to a voluntary change of residence. Migration readiness has a complex determination, ie the source of migration readiness cannot be only internal or only external. By migratory attitudes, we mean a set of orientations and motives of the agent, which are related to his desire to go abroad for different purposes. In our study, we consider emigration sentiment as a component of the migration readiness of modern youth in the context of the preconditions of potential (possible) emigration. The obtained results indicate despair, frustration, lack of vision of one's own prospects in the country, which, of course, significantly affects the formation of migration readiness. It is safe to say that migratory sentiments are widespread among Ukrainian youth. Elements of migration readiness are both external causes (the main of which are: economy, security, financial situation) and internal (features of the subjective image of the world of respondents, their values and moral orientations, the desire for selfrealization). The key motives for migration at the moment are low incomes and socio-economic factors. Accordingly, it is about what is not satisfactory in Ukraine: low income, unstable political situation and the inability to implement their professional experience.
\end{abstract}

Keywords: migration readiness, migration moods, migration behavior, values and life guidelines for schoolchildren.

Постановка проблеми. Сучасний розвиток української держави визначається як період трансформаційних процесів, пошуку власного шляху розвитку та зміни цінностей. Криза традиційних ціннісних орієнтацій особливо яскраво проявляється у сфері праці, ставленні до роботи. Так, в умовах сьогодення не «спрацьовують» колективістські ідеали, став непрестижним ряд професій, які поважали раніше та вважали суспільно корисними; змінилося ставлення до своєї батьківщини - зараз молодь бажає 
навчатися, працювати, а то й переїхати на постійне проживання до іншої країни.

Міграційна поведінка має серйозні соціальні наслідки, які необхідно враховувати i прогнозувати. Ми вважаємо важливим здійснення психологічного аналізу пї механізмів, рушійних сил і факторів. Серед можливих факторів, які впливають на міграційну поведінку особистості, ми можемо виділити формування міграційної готовності серед юнаків та трансформацію цінних орієнтацій сучасного суспільства.

Виступаючи, 3 нашої точки зору, ключовим елементом системи міграційних процесів та входячи до структури міграційної поведінки, тобто суб'єктивного виміру міграції, еміграційні настрої донині не привернули значної уваги сучасних дослідників. Частково цей феномен присутній у несистемних та ескізних роботах з міграційної тематики, а також у роботах Орбан-Лембрик Л, 2002. [2, с. 4]

В межах нашого дослідження ми розглядаємо еміграційні настрої як компонент міграційної готовності сучасного юнацтва в контексті передумов потенційної (можливої) еміграції. При цьому зазначимо, що останні далеко не завжди призводять до виїзду з країни.

Аналіз останніх досліджень і публікацій. Спираючись на досвід концептуалізації міграційних процесів, ми можемо схарактеризувати дослідницьке поле еміграційних настроїв у структурному сенсі таким чином (якщо підходити до еміграційних настроїв як до системного, комплексного явища):

1. Багаторівневий аналіз ситуацій/контекстів, в яких відбувається формування еміграційних настроїв. Це означає, що на метарівні цими контекстами є процеси глобалізації, світова економічна криза, актуалізація туристичних практик, інформатизація та інтернетизація соціального простору; на макро- та мезорівнях - процеси соціокультурної трансформації українського суспільства, зміни інститутів влади, темпів економічного зростання, інституційні зміни та структурні зрушення в соціально-груповій та професійній системі нашого суспільства; на мікрорівні - зміна системи цінностей, зразків поведінки, моделей ідентифікації акторів, емоційний та інтелектуальний фон (характерний будь-якому агентові як особистості) формування еміграційних настроїв, а також структура та специфіка повсякденності [1, с. 101].

2. Дослідження специфіки суб’єктів еміграційних настроїв. Тут центром нашої уваги має стати сучасне українське юнацтво як соціокультурна спільнота, резерв інтелектуальної еліти суспільства, інтелігенції. Суб'єкт орієнтоване дослідження передбачає також i врахування стилів життя, повсякденних практик, специфіки економічного та соціального статусу школярів та студентства. Тобто в загальному вигляді (безвідносно до нашого дослідження) суб’єктна орієнтованість дослідження еміграційних настроїв означає розкриття та пояснення процесів формування та існування 
еміграційної суб'єктності як феномену, їі детермінантів, проявів та наслідків. Це передбачає, в тому числі, і аналіз структури внутрішніх детермінант діяльності суб'єктів еміграційних настроїв (вивчення цінностей, моральних позицій, зразків поведінки, моделей ідентифікації, мотивів).

3. Дослідження мотивів еміграційних настроїв. Слідом за Рибаковським О.[3, с. 173-179], ми пропонуємо, як вже зазначалось вище, диференціювати фактори на об'єктивні (приміром, рівень життя, матеріальне становище студента та його сім’і, фах навчання і т. ін. ) і суб’єктивні елементи внутрішнього світу суб'єкта, які актуалізують у його свідомості потребу та бажання до еміграції (наприклад, моральні позиції юнаків, ціннісні орієнтації, професійні плани).

4. Дослідження хронологічного зв'язку «еміграційні настрої - установки - дії» (реальний виїзд за кордон), тобто трансформації когнітивно-емоційного феномену у феномен соціальний, екстерналізований, об'єктивований. Важливе значення для вивчення закономірностей формування еміграційної поведінки має з'ясування особливостей прийняття рішення про виїзд за кордон.

Міграція як важливе соціально-економічне явище в сучасному суспільстві має внутрішні підстави і різноманітні зовнішні прояви. При цьому важливу роль відіграють рівень домагань індивіда, його здатність задовольняти свої потреби тощо.

Отже, на процес міграції впливають різноманітні чинники: психологічні, моральні, соціальні тощо. Спочатку відбувається загострення причин, що спонукають людину до міграції, під дією зовнішніх або внутрішніх чинників. Далі послідовно розгортаються етапи міграції: формування мотиву, пошук оптимального рішення, дії, зміни, реакція і вплив мешканців нового місця переселення на дії мігранта.

Мета статті - на підставі результатів емпірико-практичного дослідження висвітлити особливості міграційної поведінки та соціально-психологічні причини еміграції сучасних українців.

Виклад основного матеріале. Вивчення феномену міграції в сучасному соціальному контексті, незважаючи на його актуальність, часто має лейтмотивом лише інструментальні дослідницькі завдання, що призводить до несистематичного характеру наукового пошуку, безумовно, цікавого та іноді евристичного, але не такого, що може призвести до конструювання універсальної схеми дослідження міграції. У цьому сенсі Ровенчак О., [4, с. 125,129], розглядаючи міжнародну міграцію крізь призму іiі причин та наслідків, відзначає, що у науковій літературі міжнародна міграція здебільшого розглядається або як причина, або як наслідок певних змін у соціальній, культурній чи особистісній площині, проте іiі причини та наслідки зазвичай не класифікуються за критеріями цих площин. У зв'язку з цим цікавою видається думка Т.Н. Юдіної, яка відзначає, що у сучасному дискурсі недостатньо враховується роль міграції як потужного чинника соціальної динаміки 
сучасного суспільства, розвитку економічних, політичних, соціокультурних процесів [5, с. 272].

Тобто системна інкорпорованість міграції як сучасного елементу відтворення все більш відкритих соціальних систем, як все більш диференційованого феномену, що вже сформував цілий спектр явищ сфери міграцій ставить перед психологією виклик єдності та уніфікованості досліджень багатоманітних міграційних процесів.

Міграційна готовність є окремим випадком психологічної готовності людини до чого-небудь. Найчастіше психологічна готовність досліджується в руслі проблематики психічних станів i трактується як фактор, який опосередковує реалізацію потенційних можливостей людини в конкретних умовах. При цьому сутність готовності розуміється неоднаково. У своєму дослідженні ми спираємося на визначення, за яким міграційна готовність - це установка, схильність суб'єкта, що виникає при передбаченні їм певного об'єкта (або ситуації) і забезпечує стійкий, цілеспрямований характер перебігу діяльності. 3 позицій теорії психологічних систем [3, с. 188-194; 4, с. 130-135] міграційна готовність розуміється, як прагнення добровільно змінити регіон проживання, що виникає у людини на основі протиріч між його образом світу, що включає i оцінку місця проживання, а також бажаного майбутнього, 3 одного боку, і його способом життя, з іншого боку, які перестали відповідати один одному.

У дослідженні брали участь різні вікові групи: учні загальноосвітніх середніх шкіл Кіровоградської області (№ 16, 17 та колегіум). У нашому емпірико-практичному дослідженні взяли участь 58 школярів 10 та 11 класів. Загальна кількість 131 особа.

Для емпіричного дослідження міграційної готовності сучасних українців ми розробили анкету, яка розкриває основні соціокультурні та ціннісноморальні аспекти цього явища.

Для систематичного аналізу отриманої інформації від респондентів, ми виділили такі блоки: соціально-культурні уявлення про свою та інші країни; міграційні уявлення і наміри; міграційні плани та міграційні готовність молоді; патріотизм молоді України; морально-культурні орієнтації молоді України.

Відповіді опитуваних школярів на питання «Чи важливо для Вас знання історичного минулого у розумінні життя країни та їі населення?» говорять про те, що молодь неоднозначно ставиться до цього питання: 3 одного боку $є$ розуміння важливості вивчення історичного минулого своєї країни (41,9\%), а 3 іншого - громадяни нашої країни можуть не надавати великої значимості історичному минулому своєї Батьківщини (52,6\%). Цікавим $\epsilon$ також порівняння процентного співвідношення відповідей. Більшість школярів (17 та 16 школа - по 53 \%, та колегіум - 75\%).

Друге питання - «Наскільки, на Вашу думку, розвинена національна ідея в Україні?» для опитуваних респондентів виявилося дискусійним. У деяких групах воно було каталізатором для цікавих обговорень про те, наскільки 
присутня чи ні національна єдність між українцями та чи є спільний шлях нації у напрямку розбудови нашої держави.

У відповідь ми отримали такі дані: 50,3\% відповіло, що національна ідея відіграє певну роль, але вона не є ключовою для важливих змін у державі. Цей результат вказує на те, що досліджувані не вважають національну ідею провідною у курсі важливих державних змін. I лише 28,5\% зазначили, що національна ідея відіграє провідну роль у розвитку держави.

Питання «Як Ви ставитеся до сучасної України як держави?» спрямоване на дослідження оцінного ставлення молоді до України як держави. Думки опитуваних розділилися таким чином: 32, 51\% вважають, що Україна не гірша за інші держави, а 37,8\% - не відчувають гордості за Україну. Такі результати вказують на суперечливе ставлення юнацтва до своєї країни. Відповіді опитуваних свідчать про те, що ставлення студентів та школярів до сучасної соціально-політичної та економічної ситуації в Україні, як значущої об’єктивної умови самореалізації в країні є досить критичним. 77,2% опитаних хвилюються через безлад в економіці, політиці та культурі у нашій державі. Така негативна оцінка умов життя у своїй країні може згубно впливати на психіку молодих людей та викликати бажання залишити іiі.

Вивчення джерел, якими користується молодь у пошуках інформації про закордонні держави дало можливість отримати таку інформацію від респондентів. Перевагу надають джерелам 3MI (33\%). Це $\epsilon$ досить передбачуваним, адже зараз основним джерелом інформації для молоді $\epsilon$ Інтернет, телебачення, преса та кінематограф. Так як питання передбачало запис власного варіанту, то 12 осіб запиши такий варіант як Інтернет, підкреслюючи роль Інтернет- мереж у своєму житті.

На жаль, інформація у Інтернеті не завжди буває правдива, вона може бути викривленою або неперевіреною. Це може створювати певні нереалістичні уявлення молоді про закордонні країни. Але, в той же час, Інтернет може дати багато можливостей для молоді у плані реалізації своїх міграційних планів. Існує безліч проектів для роботи на навчання у інших країнах, які можна знайти у мережі. Також функціонують різні соціальні програми, які надають змогу спілкування он-лайн 3 представниками інших держав.

Друге джерело, яке виділили респонденти - це подорожі за кордон та інформація від знайомих. Такий варіант відповіді обрали 2 та 21\% відповідно. I, найменш популярними виборами стали освіта $(17,4 \%)$ та книжки $(5,6 \%)$. Нажаль, респонденти вказали, що навчальні програми у навчальних закладах не надають істотної кількості інформації про закордонні держави.

У другому блоці питань анкети, ми виділили такий параметр як міграційні уявлення i прагнення молоді. Питання передбачає дослідження думки респондентів про кількість знайомих людей, які бажають переїхати за кордон.

Ми намагалися з'ясувати, яка переважаюча думка про міграцію панує 
серед юнацтва. Варіант відповіді: «Бажаючих поїхати за кордон багато» набрав найбільшу кількість голосів. (42\%). Це свідчить про значне поширення міграційних настроїв серед сучасної молоді. 23\% респондентів відповіли, що «при можливості поїхали б усі». Таким чином, результати опитування говорять про переважання відповідей, які свідчать про значну тенденцію юнацтва і молоді до потенційної міграції.

У наступному питанні «Що, на Ваш погляд, може стримувати бажаючих поїхати за кордон?» ми отримали такі результати. Основною проблемою у бажаючих переїхати за кордон $\epsilon$ нестача коштів, на думку респондентів (32,2\%). 21\% вважає, що не знання або погане знання мови іншої країни може стати перешкодою при влаштуванні життя у іншій країні. 15,6\% - відсутність контрактів на навчання або роботи.

Таким чином, молодь визнає об'єктивні причини, які можуть стати на заваді при переїзді у іншу країну. Але, може турбувати те, що саме матеріальні причини та відсутність практичних навичок (знання мови)є більш вирішальними, ніж не бажання залишати своїх друзів (всього 15,2\%). Занепад значимості родинних зв'язків може стати однією із причин поширення міграційних думок серед молоді.

Наступне питання ми включили у анкету, щоб з'ясувати, який вид закордонної поїздки найбільш прийнятний для сучасної молоді. Цікавим виявилося те, що 45,8\% відповіли - довготривалий контракт. Тобто, найбільш привабливою для них є перспектива залишитися у іншій країні на великий термін, і при цьому бути забезпеченими стабільним заробітком. Також, респонденти мали можливість вписати свій варіант відповіді на це запитання, i деякі скористалися цією можливістю, і дописували «подорож», «туристичну поїздку». 21,6 \% відповіли, що їм би була прийнятна короткочасна робота за кордоном. Загалом, у ходу бесіди, доповнювали - і щоб країну подивитися, $\mathrm{i}$ заробити грошей. Але без наміру залишатися там остаточно.

Наступним блоком у нашій анкеті $\epsilon$ міграційні плани та міграційна готовність молоді. I для виявлення міграційної готовності ми запропонували респондентам таке питання: «Чи вважаєте Ви, що сьогодні молода людина має спробувати поїздку за кордон?»

На це питання найбільше відповідей було отримано - «так» (варіант «а»). Тобто, 93,1 \% опитаних вважають, що сьогодні молода людина має спробувати поїздку за кордон. Такі пануючі уявлення свідчать про високу зацікавленість молоді у культурі інших країн, бажанні розширити свої знання про них. Але, це може стати і дестабілізуючим для тих, хто сприймає такі думки як «необхідність їхати за кордон кожній молодій людині».

Задля з'ясування ставлення молоді та юнацтва до можливостей реалізації своїх життєвих планів у майбутньому, ми одержали такі результати відповідей: більшість (60,3\%), вважають, що свої життєві плани вони змогли б краще реалізувати саме за кордоном. Тобто, у своїй країні, для переважаючої частини опитаних, можливості самореалізації є обмеженими. Це суб'єктивне 
відчуття депривації своїх можливостей може згубно впливати на психіку молоді та бажання реалізуватися як особистість та професіонал за кордоном. Інша частина опитуваних (39,6 \%) вважають, що вони могли б «знайти себе» в Україні.

Для з'ясування пануючої думки щодо майбутніх планів молоді та їх міграційних намірів, ми виявили, що респонденти обирали найбільшу кількість разів такі варіанти як «с» («якщо з'явиться нагода отримати роботу за кордоном на вигідних умовах, то я, мабуть, поїду працювати за кордон» $37,7 \%$ ) i «b» («я хочу працювати в Україні, якщо умови і заробітна плата будуть мене влаштовувати» - 36,3\%). Тобто, у старшокласників та молоді $\epsilon$ готовність змінити своє місце проживання на більш потенційно вигідне. Але у молоді $є$ також і сподівання, що заробітна плата та умови життя в Україні будуть відповідні їхнім побажанням у майбутньому. Як видно, саме економічні причини є тим стимулом, який спонукає молодь шукати кращого життя за кордоном. Із 135 чоловік тільки 26 відповіли, що вони планують жити і працювати в Україні, оскільки від кожного із нас залежить майбутнє країни.

Серед основних факторів, які можуть бути важливими під час прийняття рішення про виїзд з України, респонденти найбільшу кількість виборів віддали варіанту «рівень заробітної плати» (27,3\%) та «економічна стабільність» $(16,8 \%)$. Економічний чинник $є$ одним із найпоширеніших при прийнятті рішення про міграцію у іншу країну, але нам цікаво дослідити ще ті чинники, які не стосуються рівня доходів громадян.

Можливість професійної самореалізації обрали 18\% опитаних. Тобто, молодь має недостатньо високу оцінку можливості працювати за спеціальністю у своїй країні. Професійна нереалізація може викликати занепокоєння та бажання реалізувати свої вміння, зайняти певне становище у соціумі за кордоном. Також 15,6\% обрали» соціальну стабільність» як бажаний фактор, який вони можуть знайти у іншій країні.

Щодо соціального статусу, то статистична значимість цього зв'язку має високу достовірність (1\% значимості). Для юнаків соціальний статус відіграє важливу роль. Існує бажання змінити, покращити свій статус шляхом влаштування свого життя у іншій країні. Таке бачення свого майбутнього може бути наслідком оцінення соціального статусу у зв'язку з матеріальною вигородою за свою працю, а не іiі престижністю (адже більшість емігрантів працює не за спеціальністю). Отже, можна зробити висновок, що відношення до міграції для значної частини молоді, що не має конкретних планів виїзду, будується на установках, провідним компонентом яких є бажання здобути престижний соціальний статус.

Також ми бачимо тісний зв'язок між міграційною готовністю та таким параметром, як раціональне відношення до життя, (на 1\%-ному рівні значимості) кореляції. Можна сказати, що юнаки свідомо та раціонально розглядають можливість потенційної міграції. Орієнтація на раціональне 
відношення до життя вказує на те, що цінності юнаків, які мають міграційну готовність, загалом мають прагматичний напрямок.

Активність позиції людини у ставленні до життєвих проблем, упевненість в наявності можливостей змінити ситуацію і здатність спланувати ці зміни украй важливі для розуміння реальних чинників міграції та ії потенційного обсягу. Тому найважливішою детермінантою міграційного потенціалу $\epsilon$ суб'єктивна оцінка вміння знаходити шляхи рішення проблем як життєвий орієнтир професіонально - прагматичної групи цінностей (ступінь вірогідності 5\%).

Професіональна орієнтація також має статистично значимий зв'язок із міграційною готовністю (1\% значимості). Юнаки оцінюють професіональні вміння як чинник, який відіграє суттєву роль у реалізації міграційного бажання.

Таким чином, виділена нами група професіонально-прагматичних ціннісно-життєвих орієнтирів має тісний зв'язок із міграційною готовністю. Для юнаків цієї вибірки характерною $є$ потреба у покращенні свого соціального статусу, орієнтація на здобуття корисних знань, умінь та навичок, а також спрямованість на працю. Ця особливості особистості разом із чинниками навколишнього середовища та можливостями може формувати міграційну готовність.

Два параметри - «індивідуальність» (1\% значимості) та «почуття та емоції» (1\% значимості) - 3 другої групи цінностей, які ми охарактеризували як цінності індивідуальності, показали статистичну значущість із показниками міграційної готовності. Індивідуальність як фактор, який впливає на формування міграційної готовності, має одне із вагомих значень. Набір індивідуально-своєрідних рис характеру, особливих поглядів, переконань, устремлінь, здібностей прямим чином впливають на формування думок щодо можливої міграції.

Такий параметр, як почуття та емоції також виявився статистичнозначимим щодо балів міграційної готовності. Юнаки цієї групи, оцінюючи дану характеристику, надають вагомого значення емоційному компоненту людського життя. Можна сказати, що думки про міграцію юнаків мають не тільки раціональну складову, але і чуттєву. Мрії про краще життя у іншій країні, благополучне майбутнє можуть бути наслідком не завжди об'єктивного перебільшення нерідко в бік позитиву, уявлення про країну, куди здійснюється чи планується виїзд.

Група соціальних цінностей має статистично-значимий зв’язок із параметрами, які є цікавими для аналізу. Ми бачимо, що така цінність як віра у суспільство отримала негативний кореляційний зв'язок із балами міграційної готовності (1\% значимості). Значимість суспільства для потенційних мігрантів нівелюється, що може впливати на формування міграційної мобільності. Адже людям, які не мають переконань щодо свого громадського обов'язку перед суспільством, державою, легше залишити свою країну задля своїх особистих цілей. Можна зробити припущення, що у юнаків, які мають обернено- 
пропорційні показники за цим параметром, спостерігається недовіра до людей як частини суспільства. У більшій мірі, для них є більш прийнятним правило «покладатися тільки на самого себе, на свої сили».

Цікавим фактором є також позитивний зв'язок із ціннісним параметром «сім'я». (1\% статистичний значимості) Можна було передбачити, що для потенційних мігрантів значимість родинних зв'язків та сім'ї виявиться незначна. Адже міграційна готовність передбачає можливість довгої розлуки, або взагалі, розриву родинних зв'язків назавжди. Але аналіз результатів відповідей наших респондентів вказує на високу значимість сім'ї як цінності. Тому можна сказати, що потенційна міграція може розглядатися як можливість позитивного впливу на членів сім'ї, покращення їх умов життя.

Естетичні почуття, які ми виділили у групу духовних цінностей мають значимий зв'язок із міграційною готовністю (1\% значимості). Юнаки прагнуть до знаходження таких умов життя, які б задовольняли їх естетичні уподобання та смаки.

Отже, існує певний зв'язок ціннісно-життєвих орієнтацій юнаків із вираженістю міграційної готовності. Ми можемо охарактеризувати потенційного мігранта за характеристиками його ціннісного портрету. У нашому дослідженні, це юнак, який зацікавлений у покращенні свого соціального статусу, орієнтований на здобуття корисних знань, умінь та навичок, які б слугували більш успішній адаптації, спрямований на працю. У такого індивіда є переконання, що у складній ситуації він зможе активно діяти; віра в ефективність власних дій. Велике значення має набір індивідуальних рис, які можуть впливати на формування міграційної готовності. Адже потрібно володіти великою енергією і волею, щоб радикально змінити місце і спосіб свого життя. Значимість суспільства для потенційних мігрантів не велика.

Висновки. Таким чином, можна зробити висновок, що відношення опитаних респондентів до міграції виступає не тільки як спосіб вирішення окремих, матеріальних проблем, а й включає у себе ряд інших, психологічних чинників. Такий фактор, як набір певний ціннісних орієнтацій, може 3 більшою імовірністю сприяти формуванню міграційної готовності. Ми можемо побачити, що досліджувані, які у ході анкетування обирали відповіді, які вказують на їх потенційну міграційну спрямованість у своїй більшості демонструють переважання прагматично-професійних цінностей.

\section{Лimepamypa:}

1. Клочко В. Е. Психосинергетика: настоящее и будущее психологи. Человек в психологии: ориентиры исследований в новом столетии: Материалы конференции.Караганда: Изд-во КарГУ, 2001. С. 101.

2. Орбан-ЛембрикЛ. Е. Вплив міграційних процесів на поведінкові прояви особистості.Філософія, соціологія, психологія : зб. наук. пр. Івано-Франківськ : ВДВ ЦІТ, 2008. Вип. 13. Ч. 1. С. 3-15. 
3. Рыбаковский А. А. Миграция населения (вопросы теории).Приложение к журналу «Миграция в России».М. : ИСПИ РАН, 2003. С. 173- 194.

4. Ровенчак О. А. Міжнародна міграція крізь призму їі причин та наслідків. Вісник Львівського університету. вип. 2. 2009. Вип. 3. С. 125-142.

5. Юдина Т. Н. Социология миграции НТМ. Учебное пособие для вузов. М.: Академический Проект, 2006. 272 с.

\section{References:}

1. Klochko V. E. Psihosinergetika: nastojashhee i budushhee psihologii [Psychosynergetics: present and future of psychology]. Chelovek v psihologii: orientiry issledovanij v novom stoletii: Materialy konferencii. Karaganda: Izd-vo KarGU, 2001. S. 101.

2. Orban-LembrikL. E. Vpliv migracijnih procesiv na povedinkovi projavi osobistosti [Influence of migration processes on behavioral manifestations of personality ]. Filosofija, sociologija, psihologija : zb. nauk. pr. - Ivano-Frankivs'k : VDV CIT, 2008. Vip. 13. Ch. 1. S. 3-15.

3. Rybakovskij A. A. Migracija naselenija (voprosy teorii). [Population migration (theory issues)]. (Prilozhenie k zhurnalu «Migracija v Rossii».) M. : ISPI RAN, 2003. S. 173- 194.

4. Rovenchak O. A. Mizhnarodna migracija kriz' prizmu iii prichin ta naslidkiv [International migration through the prism of its causes and consequences].Visnik L'vivs'kogo universitetu. vip. 2. 2009. Vip. 3. C. 125-142. [in Ukrainian].

5. Judina T. N. Sociologija migracii NTM. [Sociology of NTM] migration.Uchebnoe posobie dlja vuzov. M.: Akademicheskij Proekt, 2006. 272 s. 